Миливоје В. МЛАЂЕНОВИЋ

Универзитет у Новом Саду Педагошки факултет у Сомбору
Оригинални научни рад

Примљен: 24. 12. 2018.

Прихваћен: 14. 02. 2019.

\title{
ТЕАТРОЛОШКА ДИМЕНЗИЈА У РАСПРАВАМА О ДРАМИ И ПОЗОРИШТУ ПАВЛА ПОПОВИЋА
}

\begin{abstract}
Анализом расправе „Српска драма у XIX веку” Павла Поповића која се тичу драме и позоришта, утврђује се његов специфични поглед на драму и позориште. Поповићев метод одликује поступно напуштање гледишта класичне драматургије која у позоришту заступа искључиво логоцентричну концепцију. Стога се у раду потенцирају оне оцене и описи које позорницу и све оно што се на њој може извести сматрају такође важним. Уз биографске елементе најзначајних српских драмских писаца Јоакима Вујића, Јована Стерије Поповића, Косте Трифковића и Бранислава Нушића и нијансирање типолошких разлика у сфери жанра комедије и оцена њихове књижевне вредности у контексту европске драмске традиције, Поповић говори и о еволуцији позоришног система и позоришне публике у Србији. У закључку се указује да Павле Поповић по свом приступу драми, српским драмским писцима и позоришту, представља претечу научне дисциплине која је данас означена термином театрологија. То је нарочито истакнуто у расправама о Јоакиму Вујићу и Стерији, где Поповић указујући на сценски потенцијал драмског текста, све јасније поставља границу између драмске литературе и позоришта као независне културне праксе.

Кључне речи: Павле Поповић, Јоаким Вујић, Јован Стерија Поповић, Коста Трифковић, Бранислав Нушић, театрологија, драма.
\end{abstract}

Јасно разликовање и уважавање специфичности позоришта као уметничке праксе наслућује се већ у првом поглављу студије „Српска драма у XIX веку” Павла Поповића. Наиме, говорећи о стварању српске комедије и драме, аутор истиче да су „Доситеј и Емануило Јанковић, чисти књижевници, кабинетски људи" (Поповић 1939: 143) те да се не може само помоћу књиге као што су то они чинили, радити на придобијању позоришне публике и стварању навика „на комедије” него да се мора „другим путем радити на томе, путем позоришта" (Поповић 1939: 143). Ово Поповићево запажање из перспективе данашњег проучавања позоришта и драмске књижевности не чини се нарочитим открићем: да су позориште и драма два аутономна

*milivoje_mladjenović@yahoo.com 
уметничка система сасвим је јасно, али у време када настаје ова његова синтеза (1902), театрологија се као наука споро и тешко пробијала до спознаје о свом правом предмету. Неки театролози чак сматрају да је тек пре деценијудве начињен битан корак у утемељењу театрологије као независне научне дисциплине која препознаје и дефинише предмет а потом и циљ свога истраживања на основу ког је могуће развити и метод истраживања. „Бернард Дорт је у своје 'Три ријечи о казалишту', изречене на Петом међународном симпозију казалишних критичара и театролога у Новом Саду 1982. године, устврдио да је Theaterwissenschaft или театрологија ријеч још до пред десетак година сматрана смијешном, а данас је врло популарна" (Гашпаровић 1986: 231). Ако је и тако, то не значи да садржај и предмет данашње театрологије није изучаван у оквиру других научних дисциплина (историје драмске књижевности и књижевне критике, понајпре). „Према схватањима Ерике Фишер-Лихте, еманципација теорије позоришта у односу на теорију драме (односно књижевности) настаје већ приликом тога што она назива првим перформативним обртом у европској култури 20. века тј. заснивањем театрологије као посебне науке о уметности која у центар своје пажње смешта представу мислећи је као догађај” (Илић 2018: 25). Отуд смо слободни да тврдимо да се српска театрологија као наука заснива упоредо с напорима око настанка професионалнога позоришта у Срба. И у другим националним културама било је слично стање: „литература, дакле, која је у театру тек један од равноправних сегмената, појављивала се као тоталитет” (Гашпаровић 1986: 231). У студији „Српска драма у ХІХ веку”, Поповић приступа анализи драмских дела Јоакима Вујића, Јована Стерије Поповића, Милована Глишића и Косте Трифковића и, делимично, Бранислава Нушића. Свој карактеристични биографски метод користи највише у делу студије који је посвећен Јоакиму Вујићу. Описујући Јоакимов живот и списатељски рад, он интуитивно упућује на бројне елементе који су предмет разматрања театрологије.

За развој театрологије, као дисциплине која проучава позориште у свим његовим изразима, која дакле тежи ка свеобухватности појма литерарног позоришта, биографска критика има одређеног значаја. Реч је о томе да Поповић сматра да и „прозаични документ”, на пример, један костим Молијерове жене Арманде Бежар, пронађен у инвентару његове оставштине може да помогне да се састави ,листа њених улога, по њеним улогама даље и по врсти њеног глумачког талента, одређивали су њен карактер, а по карактеру, напослетку, њен утицај на Молијера, његово цртање женских типова у комедијама" (Поповић 1939: 46).

Међутим, истраживачки је продуктивно да се сазна у ком се распону у Поповићевој студији дотичу основни предмети театрологије а то је, не само текст драме, него и представа, као изведбени конституент позоришта, позоришни простор и публика. У расправи „Српска драма у XIX веку” у којој се анализирају комедије Јоакима Вујића, Јована Стерије Поповића, Косте Трифковића, Милована Глишића и Бранислава Нушића имају неуједначену примену театролошких сазнања. У анализи театра Јоакима Вујића то се чини најизразитије, док се у анализи драмских дела Јована Стерије Поповића и 
његовог живота и доба, једва и дотичу питања театролошке природе. Дакле, сва она питања која отвара преображавање књижевног у драмско дело (комплексни простор интеракције речи са другим знаковним елементима позоришног система: декор, костим, покрет и најважнији - глумчево тело - који их обједињује) нису елаборирана. И у другим научним радовима (студијама, расправама, чланцима, приказима, белешкама) уз помоћ архивске грађе и биографских података, Поповић документује многе непознанице о великом броју српских писаца дубровачке, народне и новије књижевности XVIII и XIX века. Тако се биографски метод по својој природи показује као добар сарадник театрологије, јер је „нужно упућена на више или мање пробабилистичко грађење слике свога предмета посредовањем доступних докумената о његову изгледу и значењу. Ти су документи разноврсне провенијенције: од оних који настају тијеком процеса настајања казалишне представе до критичких просудби њена коначног резултата" (Гашпаровић 1986: 232). Павле Поповић даје у историјском низу опис кључних драмских аутора и објашњава, анализира њихове поетике, потом правилно уочава и разликује драмске облике, али и облике и стилове извођења. Он такође запажа категорије позоришних организација, као и специјализоване позоришне грађевине, препознаје слојеве публике, говори о рецепцији позоришне представе. Терминологија коју примењује је рудиментарна, али се може назрети по опису садржаја који се у модерној театрологији обухвата другим термином. Поповић се дотиче питања позоришне праксе а то јесте подручје театрологије као научне дисциплине.

Поповића одликује специфични поглед на драму и позориште, ширина погледа на контекст и опште прилике у европском театру: он је упознат са деловањем управитеља берлинскога позоришта Енгела, обавештава читаоца да је Енгел према Лаубеу био „као драматург цењена личност. Његови комади, као Благодарни син [...] били су на репертоару у Бечу” (Поповић 1939: 143). Он самоуверено, ауторитативно оцењује да су почеци српске драме у знаку преводне књижевности, да је зачета с Лесингом и Голдонијем и да је деветнаести век имао „то да ради; имао је док, док не стигну оригинални писци, да одржи преводну комедију на истој висини на којој је и примио” (Поповић 1939: 143). Анализирајући драме Јоакима Вујића објашњава нужност да се пореди Вујићев рад са Августом Коцебуем наглашавајући потребу да се „у овом прегледу српске драме обазремо и на овог немачког писца” (Поповић 1934: 158). Наведено Поповићево обзирање је врло учестало, а у ствари представља испитивање књижевних утицаја што је такође у домену интересовања модерне театрологије. Кад говори о Стерији говори о Молијеровом утицају, налази да су његови комади молијерски. У драмама Косте Трифковића образлаже прилично детаљно утицај Маривоа (Пола вина - пола вода „састављен из два Маривоа, Завештај и Љубав и случај”.

Надаље, Поповићев приступ српским драмским писцима карактерише напуштање гледишта класичне драматургије која у позоришту заступа искључиво логоцентричну концепцију. Он запажа одлично шта је „суштина и задатак комада”, како да се произведе позоришно ефектна ситуација у кома- 
ду, и тако је управо дефинише: „Та ситуација [...] је проста, позоришна, тј. онаква каква се чешће у малим позоришним комадићима износе [...] али је сва лепо припремљена, сва приказана тако да целу своју комичност производи, и да не оставља ни једну своју страну која би била неексплоатисана у тој цељи” (Поповић 1939: 204).

Анализирајући поетику Косте Трифковића Поповић такође налази специфичност „старе позоришне процедуре „у које убраја двосмисленост писама, истоветност имена, и др. Потом, анализирајући вештину састављања интриге, он дефинише специфичност овог позоришног елемента у Трифковићевој драматургији: „она зачуђава својим лепим развојем, разноликим ситуацијама које изазива и које су све врло интересантне и пријатне, неосетним припремањем тих ситуација, грациозним расплетом, најзад, који решава једну врло мучну и скоро безизлазну ситуацију" (Поповић 1939: 216). Надаље, према Поповићу „нарочити украс” Трифковићевог Љубавног писма јесте „диалог”, наглашавајући да би комад „половину своје лепоте изгубио да нема оног лепог, чисто позоришног диалога Трифковићевог” (Поповић 1939: 218). У овом исказу уочавамо синтагму „позоришни диалог” што говори о Поповићем истицању посебности дијалошке комуникације у драми која је заснована на паралелизму комичних фраза, паралелизму комичних ситуција. Тако се постиже утисак правог дијалога међу ликовима. Постиже се, оно што Павис зове кохерентношћу дијалога: „када је ситуација исказивања (цјелокупна изванјезична стварност ликова) заједничка свим говорницима" (Павис 2004: 56).

Приликом анализе Поповић уплиће и личне позоришне доживљаје што сведочи о његовом продубљеном интересовању за цео конгломерат позоришне уметности, не само за драмску књижевност, и тиме се приближава театролошком промишљању позоришног феномена. Тако, на пример, објашњавајући комични дијалог Трифковићев наводи: „ми се сећамо да смо у Дубровнику лањске године гледали комад на талијанском”. На другом месту сазнајемо да је прегледао редовно лист Позориште Српског народног позоришта.

Павле Поповић такође врло јасно нијансира типолошке разлике у сфери жанра комедије. Понекад се послужи и деминутивом да означи обим, форму драмског облика па налазимо следећу терминологију: „мали позоришни комадићи”, „комедијица”, „мала комедија” итд. Анализу комедиографског рада Јована Стерије Поповића почиње оценом да је „Стерија сасвим друкчији књижевник од Јоакима”, апострофирајући да је имао неупоредиво веће књижевно образовање од Јоакима. У писању је, утврђује, највећа разлика између њега и Јоакима и даје најсублимнији опис те разлике: „Овај преводи, а онај пише” (Поповић 1934: 172), истичући да је Стерија први оригинални комедиограф у нас.

На плану елемената драме уочава Павле Поповић да „код наших писаца имена нису најпробранија” (Поповић 1934: 223), да „лица на листи немају ни имена него се уопште зову: муж, жена, отац, мати" (Поповић 1934: 195). Таква оцена је у складу с Теновим гледиштем о употреби имена у комедији која би требало да буду таква „да су кроз своје граматичко извођење или своју сложеност или другим неким значењем наговештавале својства лика" (Тен 
1953: 89). Поповић запажа и драматуршке детаље који се односе на делове драме. Говорећи о Женидби и удадби запажа да ову малу комедију Стерија „није ни поделио у чинове него „одељења”, за Злу жену каже да је то шала „која би могла бити још много боља кад би се неке сцене скратиле или изоставиле" (Поповић 1934:187). Овај упут није ништа друго него оно што се данас у изведбеној пракси колоквијално зове - штрих. За комад Мила каже да „није комад него монолог, декламација, песма” (Поповић 1934: 209). Данашњом терминологијом тај би драмски облик био означен као монодрама.

У својим узгредним запажањима Поповић указује на специфичан статус позоришне представе која за разлику од књижевног или било ког другог уметничког дела у својој материјалној супстанци постоји у врло ограниченом временском току. Из тих разлога, говорећи о Јоакиму Вујићу, Поповић наглашава: „ми бисмо више волели да је он место говора о пустахијама [...] дао више података о својим представама и да је од свог животописа начинио мање авантуристичан роман него мемоаре једног позоришног управитеља...” (Поповић 1934: 164). Поповић се, дакле, врло конкретно, дотиче питања реконструкције позоришне представе, као битног предмета и једног од најважнијих и најсложенијих задатака модерне театрологије.

Павле Поповић се такође бави и еволуцијом позоришног система и позоришне публике у Србији, говори о приликама у којима раде књижевници које се баве драмом, о рецепцији позоришне уметничке представе. „Да се публика односила добро према тим представама, изгледа по досадашњем јасно. Доцније, Јоаким се јако љути на њу у свом животопису и назива је нерасудним глупацима, невјежама, завистницима који говоре мазгалије" (Поповић 1934: 165). Он описује мукотрпан труд Јоакима Вујића на стварању позоришне публике: „после свакојаких неприлика, успео (је) да код једне невичне и дост грубе публике, коначно одомаћи комедију и позориште" (Поповић 1934: 144). Надаље, он указује на драматичност тог позоришног мисионарства: „Јоаким није сматрао да је испод његовог достојанства играти пред једном простом публиком и правити јој 'увеселеније' [...] он (је) ипак, сиромах, и даље играо и окупљао неке позоришне дружине" (Поповић 1934: 163). Истиче Поповић како је Јоаким „мало комичан” кад, с огромним самопоуздањем, „у 'Животописанију' каже: 'Ово је целоме роду нашему познато да нитко од Сербаља до мене није се попео на театралоное позоришче пак да је на нашем сербском језику какво театрално представленије дјејствовао"” (Поповић 1934: 163). Он такође бележи и подсмехе који су пратили Јоакима због тога што је „по градови и варошима театре играо” (Поповић 1934: 163): „Јоаким овако одговара својим противницима: 'за ово његово (он сам о себи пише у трећем лицу) опшчеполезно дјело требало би ми сви јоште да му благодаримо што је он перви у целому народу нашему сербскоме био кои е театр сербски отворио. Додаје само (и не знамо што се овим разлогом морао ограђивати кад је он волео позориште само собом $)^{1}$ да је 'само своја дјела'

\footnotetext{
${ }^{1}$ Овај Поповићев исказ по својој садржини и поруци веома подсећа на, врло често експлоатисану максиму Станиславског: „Волите позориште у себи, а не себе у позоришту!”
} 
играо и то 'по примјеру почившаго Г. Волтера' који је „такожде у својим комадима , 'сам у својој персони дјејствовао.”' (Поповић 1934: 163).

Поповић поставља аутентична театролошка питања: „Каква је била дилетантска дружина кој је он покупио, у чијим су рукама биле женске улоге, шта је сам Јоаким играо, где су држане представе, каква је била публика и како су представе пролазиле, то су све питања која нам падају на памет и на која бисмо волели имати опширна одговора. На жалост таквог одговора немамо” (Поповић 1934: 164). Међутим, иако се вајка, аутор у овој студији нуди одговоре и на нека још детаљнија театролошка питања: „Јоакимова дружина била је састављена од ђака, и по свој прилици они су у почетку и женске улоге играли. Да ли су доцније жене те улоге узимале, не зна се. Ј. Ђорђевић мисли да јесу, и суди то по ономе што Јоаким озбиљно говори како су му примећивали за његове представе 'да није актера било лепо обучена, да се шлеп није лепо вукао за њом, итд."” (Поповић 1934: 165).

У студији се говори и о Јоакимовој позоришној делатности у Крагујевцу 1834. када он постаје „књажеско-србског театра директор”, уз језгровит опис статуса и мисије овог театра које је ,јамачно било многом боље него пређашња" (Поповић 1934: 167). Из описа се сазнаје да театар садржи основне карактеристике институције: стално је, дакле стабилно, не зависи искључиво од публике, управитељ је имао одређену плату, дилетантска дружина је била стална и чланови су ђаци (мушкарци који су играли и женске улоге), а репертоар је сачињен од Јоакимових комада.

Занимљиво је да Павле Поповић посвећује пажњу и, тада доиста реткој полемици, коју је изазвала негативна оцена Јоакимових представа у неком руском листу. Из ове полемике се може уочити природа позоришне критике у то време: између редова се може сазнати да је представа била нарушена „с разговори зритеља", што Јоаким у свом одговору оповргава, или боље рећи оправдава „да је публикум наипаче задовољан био” (Поповић 1934: 168). Проблематика позоришног управљања и креирања репертоарске политике такође је предмет ове расправе. Поводом појаве Косте Трифковића Поповић кличе усхићено:

Да се можемо замислити у кожи каквог управитеља позоришта после прве представе ове Трифковићеве комедије, ми бисмо могли замислити колико су тадашњи управитељи (из године 1871) морали бити срећни кад су видели да има један српски писац са тако очевидним даром за писање малих комедија [...] али каква је тек радост код тих управитеља могла бити кад су видели да је тај писац, не само вешт и сигуран, него и врло плодан, брз, увек спреман да изради још нешто слично, увек готово са ствари коју је почео, писац који по неколико комада изради, избаци, сипа као из рукава што се каже! (Поповић 1934: 203).

Поповић, дакле, осећа шта је важно српском позоришту: продукција савремених драмских дела, наглашавајући и њихов жанр - „мала комедија”. Питање које кружи непрестано у студији Поповићевој јесте и питање оригиналности: кад је реч о Јоакиму - Поповић нема дилему: „он по свој прилици није писац него само преводилац” (Поповић 1953: 170). Говорећи о Стерији, истиче његову оригиналност и укорава оне критичаре који су сумњичави у погледу Стеријине уметничке аутентичности: „Критике није било, а и кад се 
јавила једанпут на једвите јаде, она је ударила само у оптужбе о плагијату, као да је о плагијату могло бити речи код овог скроз домаћег и локалног писца" (Поповић 1934: 199). У процени драмских дела Косте Трифковића изриче нешто опрезнији став: „Кажу да Трифковић није био оригиналан него да је само преводио и прерађивао туђе комаде. Колико је то истина ми не знамо.

Само, докле год се не саопште поуздани резултати о неоригиналности овога писца, критици је дужност веровати у оригиналност његову” (Поповић 1934: 225).

Павле Поповић по свом приступу драми, српским драмским писцима и позоришту, претеча научне дисциплине која је данас означена термином театрологија, строг је у процени драмских дела Јоакима Вујића, али сматра изузетном његову улогу за оснивање позоришта у Срба: „његова је заслуга неоспорна. Он је створио позоришта у нас" (Поповић 1939: 169). Истиче његову позоришну делатност у Србији и Војводини и Београду: „могао је с највећим задовољством гледати на београдско позориште код Јелена као на своје дело." Нарочито хвали његову искрену посвећеност позоришту, без каријеристичких побуда: „кад се помисли на његово играње у Србији, човеку изгледа Јоаким симпатичнији него што се на први поглед чини: онда кад су сви његови другови долазили у Србију за чиновнике, високе „правитељствене чиновнике, наш је Јоаким дошао да буде само „директор театра” (Поповић 1939: 170). Наглашавајући Јоакимово посланство као директора позоришта, Поповић антиципира удес и модерног управника српског позоришта који ће и у другој половини двадесет првог века „главињати између романтизираног несхваћеног и разбарушеног позоришног свезнадара (пише, глуми, режира и управља), самоуправно схваћеног нешто једнакијег међу једнакима чимбеницима театра, наопако протумаченог демократског лидера у уметности, аутократе и деспота, апсолутног господара позоришта којег фаворизује новокапиталистички концепт у позоришту" (Млађеновић 2014: 43)

Расправа Павла Поповића „Српска драма у XIX веку” има битан допринос реконструкцији драмске и позоришне баштине, представља добру основу за истинско разумевање еволуције српске драматругије и театрологије. Поповићева театролошка мисао, ослоњена првенствено на тумачење драма у односу на биографију аутора и друштвене околности, наслут је савременог дискурса о театру из које ће се развити сва она велика питања о естетском искуству, сазнању и уметности. 


\section{ЛИТЕРАТУРА}

Гашпаровић 1986: D. Gašparović, Dani Hvarskoga kazališta : Građa i rasprave o hrvatskoj književnosti i kazalištu, Vol. 12 No. 1, Split: Hrvatska akademija znanosti i umjetnosti i Književni krug Split.

Илић 2018: В. Илић, Савремено позориште: естетско искуство и прступничке праксе. Нови Сад: Стеријино позорје.

Млађеновић 2015: М. Млађеновић, Управник или Мефисто нашег позорищ$m a$, Бања Лука: Агон, година IV, број 6. Народно позориште Републике Српске Бањалука. Академија умјетности Универзитета у Бањој Луци.

Павис 2004: P. Pavis, Pojmovnik teatra, Zagreb: Antibarbarus.

Поповић 1939: П. Поповић, Расправе и чланци, Београд: Српска књижевна задруга.

Тен 1953: Х. Тен, Шекспир и његови савремениии, Београд: Ново поколење.

Milivoje Mlađenović

\section{THEATRIC DIMENSION IN THE DISCUSSIONS ON DRAMA AND THEATRE BY PAVLE POPOVIĆ}

\section{(Summary)}

The analysis of the discussion $19^{\text {th }}$ Century Serbian Drama whose subjects are drama and theatre, defined his particular view on drama and theatre. His method is characterized by a gradual distancing from the classic dramaturgy which, in theatre, represents exclusively a logocentric concept. Thus, the paper highlights those assessments and descriptions which consider the stage and everything that can be performed on it important as well. By providing biographic elements of the most prominent Serbian playwrights JoakimVujić, Jovan Sterija Popović, Kosta Trifković and Branislav Nušić and nuances of typological differences in the comedy genre and the assessments of their artistic value in the context of the European dramatic tradition, Popović speaks volumes about the evolution of the theatre and theatre audience in Serbia. The conclusion highlights that PavlePopović is the forefather of the scientific discipline we nowadays call theatrology, by virtue of his approach to drama, Serbian playwrights and theatre. This is particularly prominent in discussions on Joakim Vujić and Jovan Sterija Popović where Popović makes anincreasingly clearer border between drama and theatre as an independent cultural practice by emphasizing the stage potential of a play. 